\begin{tabular}{|c|l|}
\hline Title & Release of dissolved free amino acids from biofilms in stream water \\
\hline Author(s) & Ishizawa, Say aka; Y amamoto, Y uzo; Denboh, Takashi; Ueda, Hiroshi \\
\hline Citation & $\begin{array}{l}\text { Fisheries Science, 76(4), 669-676 } \\
\text { https:/doi.org/40.1007/312562-010-0246-2 }\end{array}$ \\
\hline Issue Date & 2010-07 \\
\hline Doc URL & http://hdl.handle.net/2115/44028 \\
\hline Rights & ○ 2010 公益社団法人日本水産学会; @ 2010 The Japanese Society of Fisheries Science \\
\hline Type & article (author version) \\
\hline File Information & FS76-4_669-676.pdf \\
\hline
\end{tabular}

Instructions for use 


\section{Release of dissolved free amino acids from biofilms in stream water}

Running title: Release of amino acids from biofilms

SAYAKA ISHIZAWA ${ }^{1}$, YuZo YAMAMOTO ${ }^{2}$, TAKASHI DENBOH $^{1,2}$, and HiROSHI $\mathrm{UEDA}^{1,2^{*}}$

${ }^{1}$ Course in Environmental Aquatic Biology, Division of Biosphere Science, Graduate

School of Environmental Science, and ${ }^{2}$ Laboratory of Aquatic Bioresources and

Ecosystem, Field Science Center for Northern Biosphere, Hokkaido University, North 9

West 9, Kita-ku, Sapporo, 060-0809, Japan

*Corresponding author: Tel \& Fax: +81-11-706-2598. E-mail: hueda@fsc.hokudai.ac.jp 
ABSTRACT: We investigated the origin of dissolved free amino acids (DFAA) in stream water focusing on biofilms in the river bed by means of incubation experiments in the laboratory. Stones were placed in the Toyohira River, Hokkaido, Japan, for 3 months, allowing formation of biofilms, and then incubated for 24 hours in the laboratory at stream water temperature. After incubation, the composition and concentrations of DFAA in the incubation solution and total hydrolyzed amino acids (THAA) in biofilms were measured by a high-performance liquid chromatography. The amount of chlorophyll $a$ (Chl.a) and the number of bacteria were also measured. The DFAA concentration increased greatly in the biofilm incubation solution, but the DFAA composition (mole \%) did not change relative to the inception of incubation, where it was similar to stream water. There was no correlation between the increase in DFAA concentration and the THAA concentration, Chl.a amount, or the number of bacteria in biofilms. These results suggest that biofilms are one of the major source of DFAA in stream water.

Keywords: Dissolved free amino acids; biofilm; epilithic algae; salmon homing;

\section{Toyohira River}




\section{INTRODUCTION}

It is well known that mature salmon display an amazing ability to migrate thousands of kilometers to natal streams for reproduction after several years of oceanic feeding. Wisby and Hasler [1] proposed the olfactory hypothesis that adult salmon primarily use olfactory cues during their homing migration from the coastal sea to their natal streams. The importance of olfactory function to salmon homing has been reviewed in many behavioral, electrophysiological, and neurobiological studies [2-6]. Unlike olfactory organs of terrestrial animals, fish olfactory organs respond only to a limited number of chemicals dissolved in water, such as L-amino acids, bile acids, sex steroids, prostaglandins, and nucleotides [7]. In general, amino acids are potent odorants for fish, and the salmon olfactory organ responds sensitively to various species of amino acids $[8,9]$.

Shoji et al. [10] analyzed the compositions of dissolved free amino acids (DFAA), inorganic cations, and bile acids in waters from three streams flowing into Lake Toya, Hokkaido, Japan, and prepared artificial waters containing equivalent amounts of DFAA; the olfactory response of masu salmon Oncorhynchus masou to these artificial stream waters closely resembled olfactory responses to the corresponding natural waters. We also previously conducted behavioural experiments to determine whether artificial 
natal stream water matching the DFAA composition of natal streams had attractive effects on chum salmon $O$. keta on upstream selective movement, and found that chum salmon selected the artificial DFAA stream water [11, 12]. These results of previous electrophysiological and behavioural experiments suggest the possibility that the DFAA compositions in natal streams are odorants for Pacific salmon. However, the origin of DFAA in stream water is not yet clarified.

Changes in the DFAA compositions in stream water are attributed mainly to complicated biological processes in the watershed ecosystem. There are many possible factors affecting the DFAA compositions both inside and outside of the stream environment, such as soils, vegetation, litter, pollen, dew, and various microbial activity [13-24]. Among these factors, the roles of complex microbial communities called biofilms have been intensively investigated [25-30]. A biofilm consists of various microorganisms, and is embedded into a matrix of extracellular polymeric substances [31]. These microorganisms are composed of both photo-autotrophic and heterotrophic microbes, such as algae, fungi, protozoa and bacteria. Among them, bacteria are the most dominant, and the bacteria concentration in biofilms at the surface of aquatic reeds was three times greater than that in the water in Lake Biwa [28].

To investigate the origin of DFAA in the Toyohira River, Hokkaido, Japan, the 
DFAA releasing activity of microbes in the river bed was examined by means of biofilm and unialgal incubation in the laboratory. In the incubation experiments, biofilms were formed by placing river stones in the Toyohira River for 3 months, allowing microbes to attach, and epilithic algae were isolated from biofilm suspensions in the Toyohira River. After incubation, the concentration and composition of DFAA in the incubation solution were analyzed by a high performance liquid chromatography (HPLC), and the amount of chlorophyll $a$ (Chl. $a$ ) and the number of bacteria in biofilms were analyzed by a fluorometer and 4'-6-diamino-2-phenylindole (DAPI) staining, respectively. Finally, the possible mechanisms of DFAA release from biofilms into stream water are discussed.

\section{Materials and methods}

\section{Study site}

The Toyohira River flows through Sapporo City, Hokkaido, and is a tributary of the Ishikari River which discharges into Ishikari Bay. The source of the Toyohira River is a mountain stream between Mt. Koizari and Mt. Fure. This river has $859 \mathrm{~km}^{2}$ basin area and is $72.5 \mathrm{~km}$ in length. In the 1950s, many chum salmon returned annually to the Toyohira River for spawning, but since the 1960s, no salmon have been found, due to declining stream water quality. Citizen efforts to reduce pollution began in the 1970s, 
and now many salmon have returned. Sampling was conducted at one site in the middle of the main body of the Toyohira River, several meters upstream of its confluence with the Makomanai River, in the urban area of Sapporo City.

\section{Biofilm incubation experiment}

One large stream bed stone was collected from the sampling point in August, 2008, and was then cut into many $10 \times 9 \times 1 \mathrm{~cm}^{3}$ sections. These individual stone sections were sunk within a nylon mesh bag (mesh size: $1 \mathrm{~cm}^{2}$ ) at the bottom of the sampling point again, and left for 3 months. The depth of water and average water velocity of sampling point was $1.3 \mathrm{~m}$ and $0.3 \mathrm{~m} / \mathrm{s}$, respectively. Microbes subsequently attached at the surface of these stones and formed biofilms.

Twelve liters of stream water and 3 stones with biofilms were separately transported to the laboratory in a cold box in November, 2008. The stream water was pressure-filtered with both a prefilter (GS-25, Advantec, Toyo Roshi Kaisha, Tokyo, Japan ) and a $0.45 \mu \mathrm{m}$ filter (Membrane filter 0.45 HA, Millipore, Billerica, MA, USA), and a $1 \mathrm{l}$ portion of this was poured into aerated bottles. Three replicate bottles with or without stones were prepared as biofilm and control groups, respectively. Incubation was for 24 hours at the in situ river water temperature of $2^{\circ} \mathrm{C}$ under $9 \mathrm{~h}$ light $15 \mathrm{~h}$ dark 
conditions following light condition in November in Sapporo. After incubation, the concentration and composition of DFAA in the incubation solution and the total hydrolyzed amino acids (THAA) in biofilms were analyzed by a high-performance liquid chromatography (HPLC). The amount of chlorophyll $a$ (Chl.a) was measured with a fluorometer (FLOM). The number of bacteria was determined by DAPI staining.

\section{Unialgal incubation experiment}

Epilithic microalgae were scraped with a toothbrush from stream bed stones at the sampling point in May, 2008, and placed into two bottles. One sample was immediately fixed with $25 \%$ glutaraldehyde and the algal taxa were identified by a light microscope. The other sample was kept alive and taken to our laboratory. Single algal cells were isolated from the sample suspension by either dilution method or micropipette washing, and were incubated for 3 weeks in culture tubes in unsterilized condition containing 10 ml CSi medium (Table 1) under a bank of cool white fluorescent lamps at 4,000 lux at the distance of $10 \mathrm{~cm}$ on a $16 \mathrm{~h}$ light and $8 \mathrm{~h}$ dark cycle at $15^{\circ} \mathrm{C}$ in the incubation chamber. To examine extracellular release of DFAA from epilithic microalgae, unialgal incubation strains of 6 dominant species were selected. There were few differences of these 6 dominant species between in May in November in the Toyohira River. A $1 \mathrm{ml}$ 
aliquot of the unialgal strain was inoculated into each Erlenmeyer flask containing 30

$\mathrm{ml}$ of CSi medium in triplicates. After incubation, the unialgal suspension was filtered by glass fiber filter (GF/F, Whatman, Kent, UK), and the concentration and composition of DFAA within the incubation solution determined by HPLC, along with concentration of Chl.a by FLOM.

\section{Determination of DFAA and THAA}

DFAA were determined according to the methods of Chen et al. [19]. Since stream water and incubation solutions contained low levels of DFAA, about $1 \mathrm{l}$ of stream water and incubation solution was concentrated to yield powdery, dry material by a rotary evaporator (EYELA N-1000, Tokyo Rikakikai, Tokyo, Japan). The powdery material was dissolved in $1 \mathrm{~N} \mathrm{HCl}$, and $\mathrm{pH}$ was adjusted to 7 with $1 \mathrm{~N} \mathrm{NaOH}$. THAA were measured according to the methods of Cowie et al. [32] with the minor modifications of hydrolyzation of biofilms with $6 \mathrm{~N} \mathrm{HCl}$ at $105^{\circ} \mathrm{C}$ for 24 hours, and $\mathrm{pH}$ adjusted to 7 with $1 \mathrm{~N} \mathrm{NaOH}$. Both samples were subjected to the anion-exchange HPLC (LC-VP, Shimadzu, Kyoto, Japan) that was repeated 3 times to reduce measurement error. o-Phtaldialdehyde-2-mercaptoethnol (OPA) was used to yield fluorescent products, and the fluorescence of the individual OPA-derivatives was measured by a RF-10 AXL 
fluorescent detector (Shimazu; excitation $350 \mathrm{~nm}$ and emission $450 \mathrm{~nm}$ ). Seventeen

L-amino acids can be analyzed by HPLC: Ala, Arg, Asp, Cys, Glu, Gly, His, Ile, Leu, Lys, Met, Phe, Pro, Ser, Thr, Tyr, Val.

\section{Measurement of Chl. a}

The amount of Chl.a was measured according to the methods of Arar and Collins

[33]. Both the sample suspensions collected from $1 \mathrm{~cm}^{2}$ of incubated biofilms and unialgae were filtered with a glass fiber filter (GF/F, Whatman) by vacuum filtration. Chlorophyllous pigments were extracted using $N, N$-dimethylformamide, and the concentrations of Chl. $a$ and pheophytin $a$ in the extracts were measured by FLOM (10-AU, Turner Designs, California, USA).

\section{Bacterial biomass in the biofilm}

The numbers of bacteria were counted by the DAPI staining technique [34]. Before DAPI staining, peptides and short chain carbohydrates that may interact with fluorescent dye had been previously removed according to the methods of Nosyka et al. [29] to reduce the resulting background noise. 


\section{Statistics}

All data are expressed as means \pm SEM. Statistical differences were determined using Student's t-test, significant at $P<0.05$.

\section{Results}

\section{Biofilm incubation experiment}

The concentration of DFAA in incubation solutions are shown in Table 2. Twelve amino acids (Asp, Thr, Ser, Glu, Pro, Gly, Ala, Val, Ile, Leu, Tyr, His) were detected from all incubation solutions. There was no difference in the average concentration of total DFAA in the control solution between 0 hour $(162.56 \pm 7.55 \mathrm{nM})$ and 24 hours $(157.09 \pm 4.77 \mathrm{nM})$. In contrast, the average concentration of total DFAA in the biofilm group increased significantly from $167.32 \pm 17.35 \mathrm{nM}$ (0 hour) to $812.87 \pm 247.12 \mathrm{nM}$ (24 hours). In spite of this great increase, the DFAA composition (mole \%) after 24 hours incubation remained nearly equivalent to the inception of incubation (Fig.1).

The THAA concentration, the amount of Chl.a, the numbers of bacteria per $1 \mathrm{~cm}^{2}$ of biofilm, and increase in DFAA of the 3 stones after $24 \mathrm{~h}$ incubation are shown in Table 3. There were no significant correlations among these factors. The composition of THAA (mole \%) in the biofilm is shown in Figure 2. The composition of THAA 
detected in biofilm was only slightly different from that of DFAA detected in the incubation solution: the ratio of Ser decreased, and the ratios of Ala, Asp, Glu, Gly, Leu, Pro, Thr and Val increased slightly, while Tyr was not detected. There were some differences in THAA composition among each stone: specifically, Asp, Glu and Ser differed (Fig. 2).

\section{Unialgal incubation experiment}

Five diatoms (Fragilaria crotonensis, Fragilaria capucina, Rhoicosphenia

abbreviata, Synedra rumpens v. familiaris, Synedra minuscula grunow) and one

yellow-green alga (Heterococcus viridis) were separately incubated under the same conditions. Since a significant amount of a compound that has the same retention time as His was detected in the medium itself, His was excluded from the analysis. Table 4 shows the concentration and composition of DFAA in the incubation solution released from each of the alga. Even after 3 weeks incubation, the total concentration of DFAA in each unialgal incubation solution was low $(5.80 \pm 0.37 \mathrm{nM}-10.34 \pm 0.37 \mathrm{nM})$ in comparison with the biofilm incubation for 24 hours.

\section{Discussion}


Although only 3 stones were used in the biofilm incubation experiment, we have clearly demonstrated that biofilms released a significant amount of DFAA into stream water. However, the degree of DFAA concentration differed greatly among each stone. Even though each stone was sunk in the river at the same time, place and duration, the THAA concentration, the amount of Chl.a, and the number of bacteria were considerably different within them. These differences may be explained by several micro-environmental factors that significantly affecting growth of biofilms: (1) differences in current speed influenced by the surrounding stones might result in differing compositions of microbes and the variation in settlement of the microbial community at each stone's surface; (2) the sorption of dissolved organic matter to biofilms might differ among stones; and (3) variation in light conditions at the surface of individual stones might also affect the growth of epilithic microalgae. Nevertheless, since the DFAA composition in each incubation solution changed little after $24 \mathrm{~h}$ incubation, the THAA composition did not affect DFAA release from biofilm. The difference of concentration and composition of amino acids between THAA and DFAA might be reflected on the difference between binding and free forms of amino acids. Since the DFAA composition released from biofilm was similar to that of stream water, this release should have crucial effects on the DFAA concentration and composition in 
stream water.

In contrast, only a small amount of DFAA was produced by epilithic microalgae in the unialgal incubation experiments. DFAA released from epilithic microalgae may have a little influence on the total DFAA concentration of stream water. However, since the abundance of the epilithic microalgae varies seasonally [35], the effect of DFAA produced by the epilithic microalgae on the stream DFAA concentration may similarly vary. According to the river continuum concept, the epilithic microalgae cannot live without both light and water, so they mainly live in an appropriate depth near the middle of a river, distant from riparian trees and shallows [36]. Although further detailed study is needed to examine the seasonal productivity of epilithic microalgae, the DFAA released from epilithic microalgae may have minimal impact on the DFAA concentration in stream water.

There may be several possible processes in which biofilms release DFAA into stream water: (1) epilithic and planktonic aminopeptidase activity [15] and/or periphytic extracellular aminopeptidase activity [18]; (2) viral lysis of bacteria [23]; (3) excretion from living phytoplankton [37]; (4) sloppy feeding by protozoa; (5) breakdown or decomposition of protein substances by microbes. There are many species of microbe that have different types of metabolic function in biofilms [26]. Among several possible 
input pathways of DFAA, the critical pathway that releases DFAA whose composition are the same as stream water is unknown yet. It is interested to consider extracellular aminopeptidases of epilithic microbes on the surface of biofilms. DFAA may be secreted from microbes free-living in the interface between the water and the biofilm surface, from attached microbe cell walls, or within the periplasm of gram-negative bacteria [15].

The DFAA concentration in stream water should increase with length of flow. However, the total DFAA concentration is almost the same throughout the Toyohira River. Since the utilization and release of DFAA by complicated biological processes occurs in fluxes along the stream ecosystem, future careful study should examine seasonal and yearly changes in the concentration and composition of DFAA along the Toyohira River watershed. Since juvenile salmon carry out downstream migration in spring and adult salmon make upstream migration in autumn of several years later, these seasonal and yearly changes in DFAA may have large influences on olfactory discriminating abilities of natal stream odorant in salmon. The seasonal and yearly changes in the concentration and composition of DFAA along the Teshio River watershed are now investigating in our laboratory. 


\section{Acknowledgments}

We thank Prof. Taizo Motomura, Field Science Center for Northern Biosphere, Hokkaido University, for his help in conducting unialgal incubation experiments. This study was partially supported by Grant-in-Aid for Scientific Research (A) (18208017) from JSPS, a natural science grant (35-4) from the Mitsubishi Foundation, and an environmental research grant (08-A10) from the Mitsui \& Co. Ltd to H. U.

\section{REFERENCES}

1. Wisby WJ, Hasler AD. Effect of olfactory occlusion on migrating silver salmon $(O$. kisutch). J. Fish. Res. Board Can. 1954; 11: 472-478.

2. Hasler AD, Scholz AT. Olfactory imprinting and homing in salmon. Springer-Verlag, Berlin. 1983.

3. Stabell OB. Olfactory control of homing behaviour in salmonids. In: Hara TJ (ed). Fish Chemoreception. Chapman \& Hall, London. 1992; 249-270.

4. Quinn TP. The behavior and ecology of Pacific salmon and trout. University of Washington Press, Seattle. 2005.

5. Ueda H, Yamamoto Y, Hino H. Physiological mechanisms of homing ability in sockeye salmon: from behavior to molecules using a lacustrine model. In: Woody 
CA (ed). Sockeye salmon evolution, ecology, and management. Am. Fish. Soc.

Symp. 54, Bethesda. 2007; 5-16.

6. Hino H, Miles NG, Bandoh H, Ueda H. Molecular biological research on olfactory chemoreception in fishes. J. Fish Biol. 2009; 75: 945-959.

7. Hara TJ. Mechanism of olfaction. In: Hara TJ (ed). Fish Chemoreception. Chapman \& Hall, London. 1992; 150-170.

8. Hara TJ. Structure-activity relationships of amino acids as olfactory stimuli. In: Hara TJ (ed). Chemoreception in Fishes. Elsevier, Amsterdam. 1982; 135-157.

9. Hara TJ. Olfactory response to amino acids in rainbow trout: revisited. In: Reutter K, Kapper BG (eds). Fishes Chemosenses. Science Publishers Inc., Enfield. 2005; 31-64.

10. Shoji T, Ueda H, Ohgami T, Sakamoto T, Katsuragi Y, Yamauchi K, Kurihara K. Amino acids dissolved in stream water as possible home stream odorants for masu salmon. Chem. Sen. 2000; 25: 533-540.

11. Shoji T, Yamamoto Y, Nishikawa D, Kurihara K, Ueda H. Amino acids in stream water are essential for salmon homing migration. Fish Physiol. Biochem. 2003; 28: 249-251.

12. Yamamoto Y, Ueda H. Behavioral responses to natal stream water amino acids in 
migratory chum salmon. Zool. Sci. 2009; 26: 778-782.

13. Fiebig DM. Fates of dissolved free amino acids in groundwater discharged through stream bed sediments. Hydrobiol. 1992; 235/236: 311-319.

14. Thomas JD. The role of dissolved organic matter, particularly free amino acids and humic substances, in freshwater ecosystems. Freshw. Biol. 1997; 38: 1-36.

15. Ainsworth AM, Goulder R. Epilithic and planktonic leucine aminopeptidase activity and leucine assimilation along the River Tweed, Scottish Borders. Sci. Total Environ. 2000; 251/252: 83-93.

16. Scheller E. Amino acids in dew - origin and seasonal variation. Atmos. Environ. 2001; 35: 2179-2192

17. Friedel JK, Scheller E. Composition of hydrolysable amino acids in soil organic matter and soil microbial biomass. Soil Biol. Biochem. 2002; 34: 315-325.

18. Francoeur SN, Wetzel RG. Regulation of periphytic leucine-aminopeptidase activity. Aquat. Microb. Ecol. 2003; 31: 249-258.

19. Chen J, Li Y, Yin K, Jin H. Amino acids in the Pearl River Estuary and adjacent waters: origins, transformation and degradation. Cont. Shelf Res. 2004; 24: 1877-1894.

20. Linares F. Effect of dissolved free amino acids (DFAA) on the biomass and 
production of microphytobentic communities. J. Exp. Mar. Biol. Ecol. 2006; 330: 469-481.

21. Linares F, Sundbäck K. Uptake of dissolved free amino acids (DFAA) by microphytobentic communities. Aqua. Microb. Ecol. 2006; 42:175-186.

22. Hawkins JMB, Scholefild D, Braven J. Dissolved free and combined amino acids in surface runoff and drainage waters from drained and undrained grassland under different fertilizer management. Environ. Sci. Technol. 2006; 40: 4887-4893.

23. Middelboe M, Jørgensen NOG. Viral lysis of bacteria: an important source of dissolved amino acids and cell wall compounds. J. Mar. Biol. Assoc. U. K. 2006; 86: 605-612.

24. Duan S, Bianchi TS. Particulate and dissolved amino acids in the lower Mississippi and Pearl Rivers (USA). Mar. Chem. 2007; 107: 214-229.

25. Kinniment SL, Wimpenny JWT. Measurements of the distribution of adenylate concentrations and adenylate energy-charge across Pseudomonas aeruginosa Biofilms. Appl. Environ. Microbiol. 1992; 58: 1629-1635.

26. Costerton JW, Lewandowski Z, Debeer D, Caldwell D, Korber D, James G. Biofilms, the customized microniche. J. Bacteriol. 1994; 176: 2137-2142.

27. Romani AM, Guasch H, Munoz I, Ruana J, Vilalta E, Schwartz T, Emtiazi F, 
Sabater S. Biofilm structure and function and possible implications for riverine DOC dynamics. Microb. Ecol. 2004; 47: 316-328.

28. Yamamoto M, Murai H, Takeda A, Okunishi S, Morisaki H. Bacterial flora of the biofilm formed on the submerged surface of the reed Phragmites australis. Microb. Environ. 2005; 20: 14-24.

29. Nosyka O, Haseborg ET, Metzgera U, Frimmel FH. A standardized pre-treatment method of biofilm flocs for fluorescence microscopic characterization. J. Microbiol. Meth. 2008; 75: 449-456.

30. Lawrence JR, Zhu B, Swerhone GDW, Roy J, Wassenaar LI, Topp E, Korber DR. Comparative microscale analysis of the effects of triclosan and triclocarban on the structure and function of river biofilm communities. Sci. Total Environ. 2009; 407: 3307-3316.

31. Freeman C, Lock MA. The biofilm polysaccharide matrix - a buffer against changing organic substrate supply. Limnol. Oceanogr. 1995; 40: 273-278.

32. Cowie GL, Hedges JI, Calvert SE. Sources and relative reactivities of amino acids, neutral sugars, and lignin in an intermittently anoxic marine environment. Geochim. Cosmochim. Acta. 1992; 56: 1963-1978.

33. Arar EJ, Collins GB. Method 445.0 In Vitro Determination of Chlorophyll a and 
Pheophytin a in Marine and Freshwater Algae by Fluorescence. Revision 1.2 U.S Environmental Protection Agency, Cincinnati, Ohio. 1997.

34. Porte KG, Feig YS. The use of DAPI for identifying and counting aquatic microflora. Limnol. Oceanog. 1980; 25: 943-948

35. Fong P, Zedler JB. Temperature and light effects on the seasonal succession of algal communities in shallow coastal lagoons. J. Exp. Mar. Biol. Ecol. 1993; 171: 259-272.

36. Vannote RL, Minshall GW, Cummins KW, Sedell JR, Cushing CE. River continuum concept. Can. J. Fish. Aquat. Sci. 1980; 37: 130-137.

37. Braven J, Butler EI, Chapman J, Evens R. Changes in dissolved free amino acid composition in sea water associated with phytoplankton populations. Sci. Total Environ. 1995; 172: 145-150. 


\section{Figure legends}

Fig. 1 The average percentage composition (mol \%) of DFAA in the incubation solution of the biofilm group at 0 and 24 hours $(n=3)$

Fig. 2 The percentage of composition (mol \%) of THAA biofilms in each stone $(n=3)$ 
Table 1 The composition of the CSi medium

\begin{tabular}{|c|c|}
\hline CSi medium & Amount \\
\hline $\mathrm{Ca}\left(\mathrm{NO}_{3}\right)_{2} \cdot 4 \mathrm{H}_{2} \mathrm{O}$ & $15 \mathrm{mg}$ \\
\hline $\mathrm{KNO}_{3}$ & $10 \mathrm{mg}$ \\
\hline$\beta-\mathrm{Na}_{2}$ glycerophosphate $\cdot 5 \mathrm{H}_{2} \mathrm{O}$ & $5 \mathrm{mg}$ \\
\hline $\mathrm{MgSO}_{4} \cdot 7 \mathrm{H}_{2} \mathrm{O}$ & $4 \mathrm{mg}$ \\
\hline Vitamin B12 & $0.01 \mu \mathrm{g}$ \\
\hline Biotin & $0.01 \mu \mathrm{g}$ \\
\hline Thiamine $\mathrm{HCl}$ & $1 \mu \mathrm{g}$ \\
\hline P IV metals ${ }^{1)}$ & $0.3 \mathrm{ml}$ \\
\hline Tris (hydroxymethyl) aminomathane & $500 \mathrm{~g}$ \\
\hline $\mathrm{Na}_{2} \mathrm{SiO}_{3} \cdot 9 \mathrm{H}_{2} \mathrm{O}$ & $10 \mathrm{mg}$ \\
\hline Distilled water & $99.7 \mathrm{ml}$ \\
\hline $\mathrm{pH}$ & 7.5 \\
\hline
\end{tabular}

1) The composition of PIV metals

\begin{tabular}{cc}
\hline P IV metals & Amount \\
$\mathrm{FeCl}_{3} \cdot 6 \mathrm{H}_{2} \mathrm{O}$ & $19.6 \mathrm{mg}$ \\
$\mathrm{MnCl}_{2} \cdot 4 \mathrm{H}_{2} \mathrm{O}$ & $3.6 \mathrm{mg}$ \\
$\mathrm{ZnSO}_{4} \cdot 7 \mathrm{H}_{2} \mathrm{O}$ & $2.2 \mathrm{mg}$ \\
$\mathrm{CoCl}_{2} \cdot 6 \mathrm{H}_{2} \mathrm{O}$ & $0.4 \mathrm{mg}$ \\
$\mathrm{Na}_{2} \mathrm{MoO}_{4} \cdot 2 \mathrm{H}_{2} \mathrm{O}$ & $0.25 \mathrm{mg}$ \\
$\mathrm{Na}_{2} \mathrm{EDTA} \cdot 2 \mathrm{H}_{2} \mathrm{O}$ & $100 \mathrm{mg}$ \\
Distilled water & $100 \mathrm{ml}$
\end{tabular}


Table 2 The concentration of DFAA in the control and biofilm solutions of biofilm incubation experiment. Each sample was measured in 3 times and presented as mean $\pm \operatorname{SEM}(n=3)$

ND: not detected

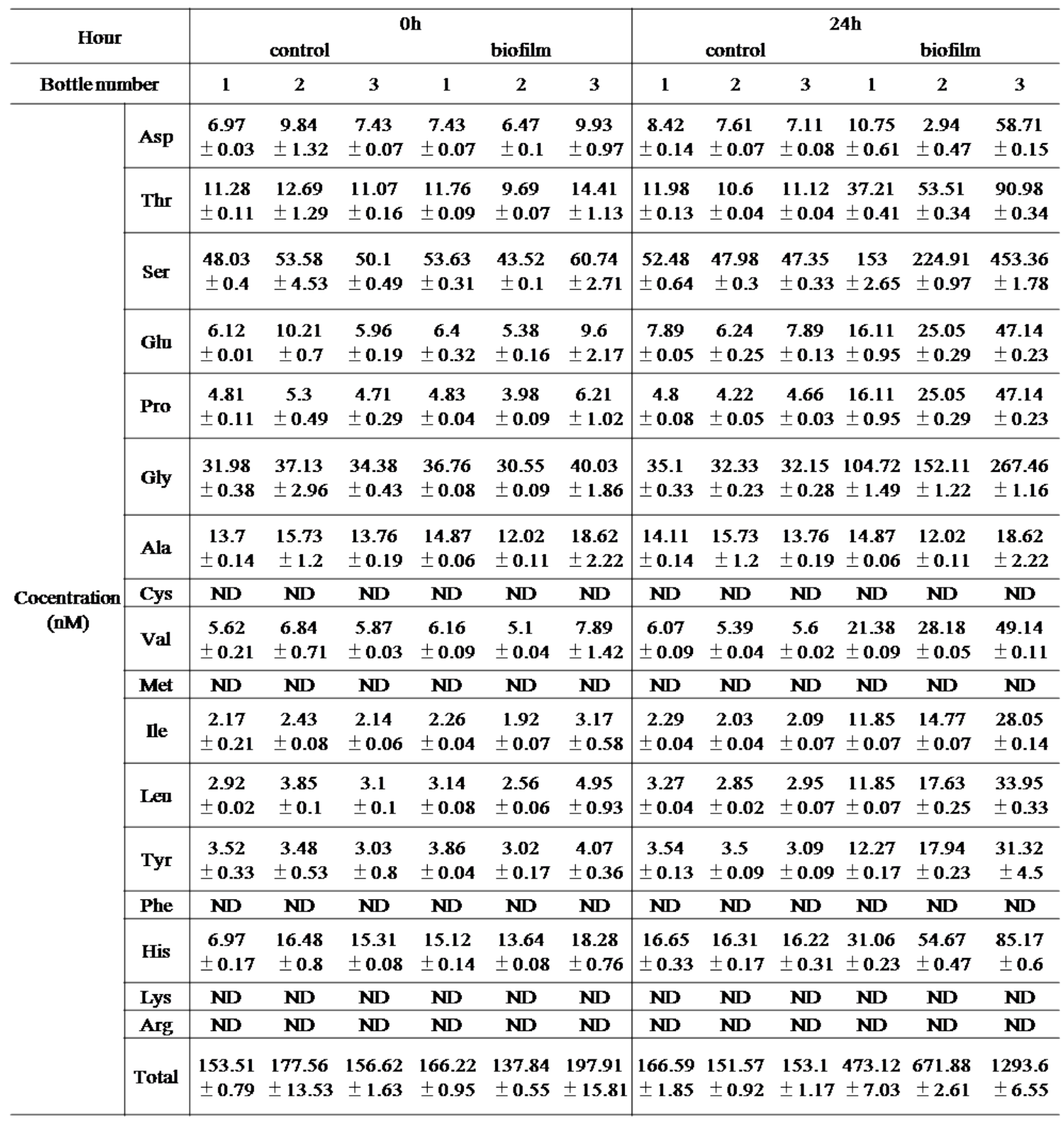


Table 3 The concentration of THAA, Chl.a, the number of bacteria per $1 \mathrm{~cm}^{2}$ biofilm, and increase amount of DFAA in the incubation solution for each stone. Each sample was measured in 3 times and presented as mean \pm SEM ( $n=3$ )

\begin{tabular}{|c|c|c|c|}
\hline & Stone 1 & Stone 2 & Stone 3 \\
\hline Concentration of THAA (nM) & $\begin{array}{l}11.57 \\
\pm 0.18\end{array}$ & $\begin{array}{r}10.33 \\
\pm 0.09\end{array}$ & $\begin{array}{c}9.98 \\
\pm 0.07\end{array}$ \\
\hline Chl. $a\left(\mathrm{ng} / \mathrm{cm}^{2}\right)$ & $\begin{array}{l}214.49 \\
\pm 0.34\end{array}$ & $\begin{array}{l}150.76 \\
\pm 3.06\end{array}$ & $\begin{array}{l}255.15 \\
\pm 4.29\end{array}$ \\
\hline Number of bacteria (population/ $\mathrm{cm}^{2}$ ) & $\begin{array}{c}1.12 \times 10^{9} \\
\pm 6.68 \times 10^{7}\end{array}$ & $\begin{array}{c}4.07 \times 10^{8} \\
\pm 9.30 \times 10^{7}\end{array}$ & $\begin{array}{c}7.53 \times 10^{8} \\
\pm 4.36 \times 10^{7}\end{array}$ \\
\hline Increase amount of DFAA (nM) & $\begin{array}{l}310.56 \\
\pm 7.03\end{array}$ & $\begin{array}{l}509.32 \\
\pm 2.61\end{array}$ & $\begin{array}{c}1131.04 \\
\pm 6.55\end{array}$ \\
\hline
\end{tabular}


Table 4 The concentration of DFAA in the incubation solution of unialgal incubation experiment. Each sample was measured in 3 times and presented as mean \pm SEM $(n=3)$

ND: not detected

\begin{tabular}{|c|c|c|c|c|c|c|c|}
\hline & & $\begin{array}{l}\text { Fragilaria } \\
\text { crotonensis }\end{array}$ & $\begin{array}{l}\text { Fragilaria } \\
\text { capucina }\end{array}$ & $\begin{array}{c}\text { Rhoicasphenia } \\
\text { abbreviata }\end{array}$ & $\begin{array}{c}\text { Synedra rumpens } \\
\text { v.familiaris }\end{array}$ & $\begin{array}{c}\text { Synedra minuscule } \\
\text { grunow }\end{array}$ & $\begin{array}{c}\text { Heterococcus } \\
\text { viridis }\end{array}$ \\
\hline \multirow{17}{*}{$\begin{array}{l}\text { Concentration } \\
\text { (nM) }\end{array}$} & Asp & $0.38 \pm 0.23$ & ND & $0.19 \pm 0.1$ & ND & ND & ND \\
\hline & Thr & $1.65 \pm 1.56$ & ND & ND & ND & ND & ND \\
\hline & Ser & $0.33 \pm 0.16$ & ND & $1.50 \pm 1.22$ & ND & $2.82 \pm 1.21$ & $2.74 \pm 1.39$ \\
\hline & Glu & $0.17 \pm 0.17$ & $5.90 \pm 0.38$ & $0.24 \pm 0.09$ & $5.97 \pm 0.32$ & $0.20 \pm 0.2$ & ND \\
\hline & Pro & $2.41 \pm 1.17$ & $1.25 \pm 1.25$ & $0.71 \pm 0.71$ & $2.80 \pm 0.36$ & $2.34 \pm 1.22$ & $1.77 \pm 0.9$ \\
\hline & Gly & $0.65 \pm 0.31$ & $0.33 \pm 0.27$ & $0.18 \pm 0.18$ & $0.38 \pm 0.33$ & $0.70 \pm 0.34$ & $0.77 \pm 0.34$ \\
\hline & Ala & $0.11 \pm 0.11$ & ND & ND & ND & ND & ND \\
\hline & Cys & ND & ND & ND & ND & ND & ND \\
\hline & Val & $1.12 \pm 0.34$ & $0.66 \pm 0.11$ & $2.33 \pm 1.18$ & $0.73 \pm 0.11$ & $1.97 \pm 1.13$ & $2.55 \pm 1.58$ \\
\hline & Met & ND & ND & ND & ND & ND & ND \\
\hline & Ile & $0.79 \pm 0.79$ & ND & ND & ND & ND & ND \\
\hline & Leu & ND & ND & ND & ND & ND & ND \\
\hline & Tyr & $2.73 \pm 1.33$ & ND & $0.55 \pm 0.31$ & ND & $0.09 \pm 0.09$ & $0.01 \pm 0.01$ \\
\hline & Phe & ND & ND & $0.11 \pm 0.06$ & ND & ND & ND \\
\hline & Lys & ND & ND & ND & ND & ND & ND \\
\hline & Arg & ND & ND & ND & ND & ND & ND \\
\hline & Total & $10.34 \pm 0.37$ & $8.14 \pm 1.56$ & $5.80 \pm 0.86$ & $9.89 \pm 0.76$ & $8.12 \pm 1.3$ & $7.84 \pm 1.07$ \\
\hline
\end{tabular}




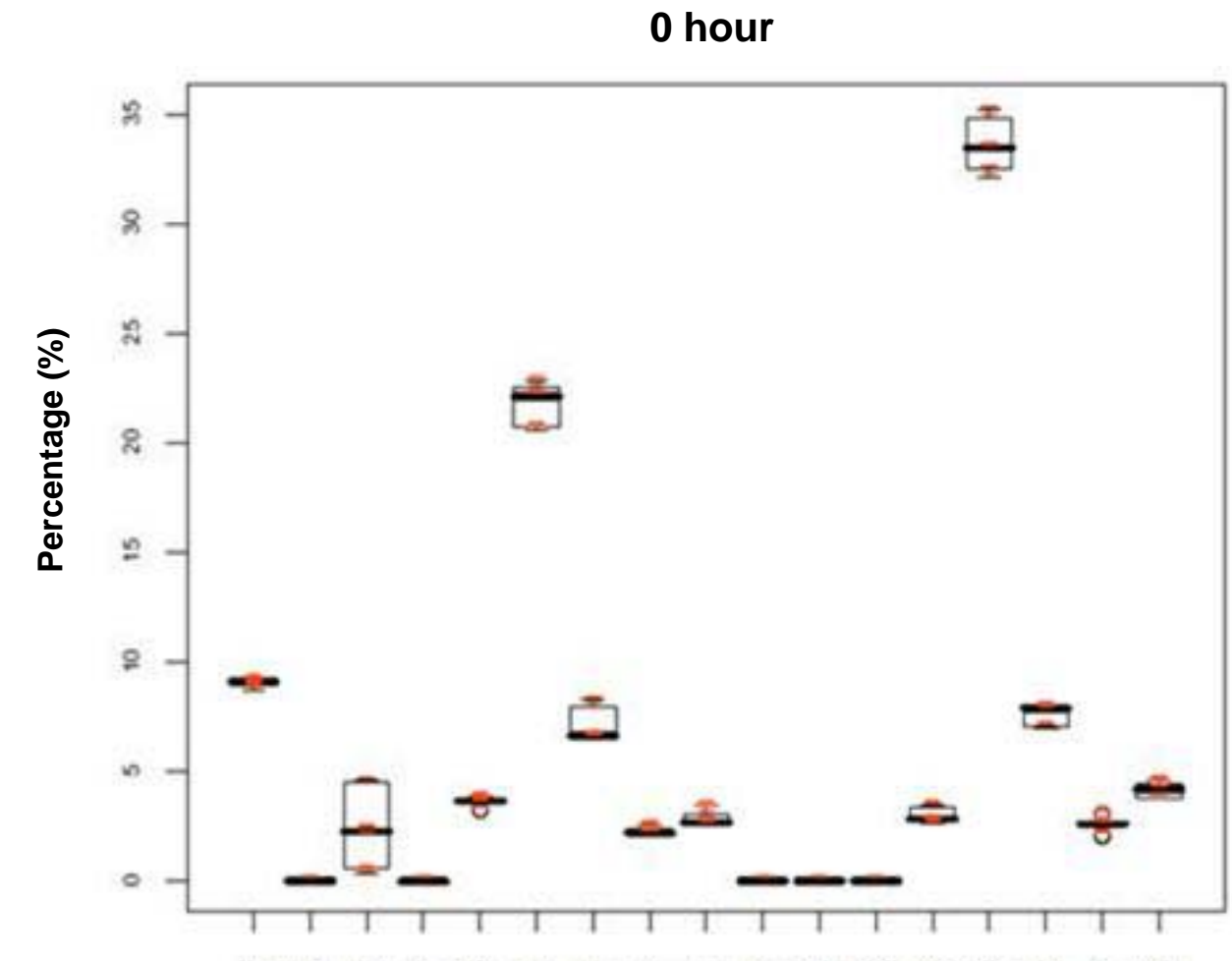

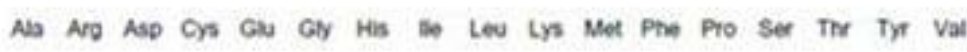

Amino acids

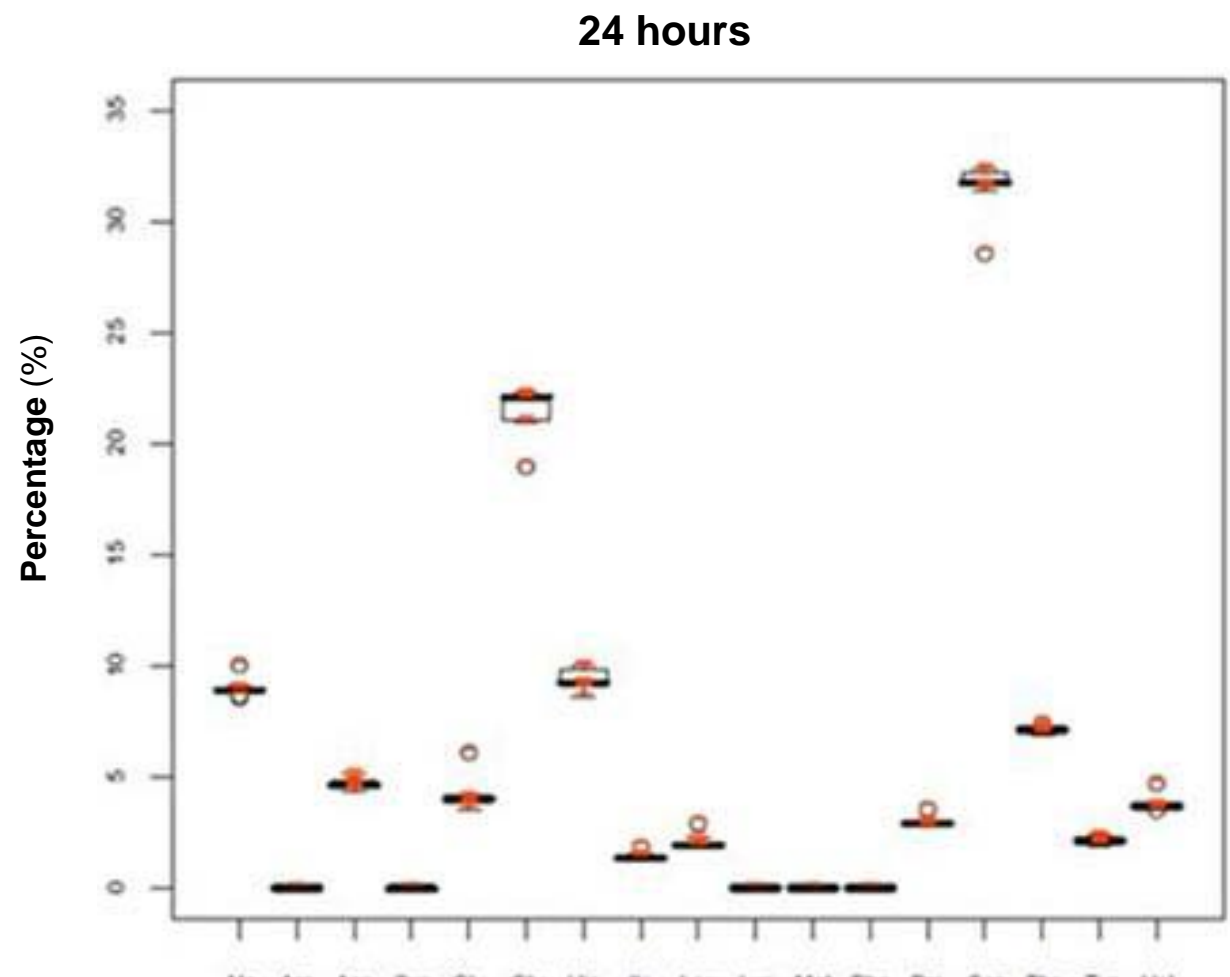

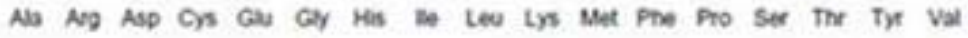

Amino acids

Figure 1 


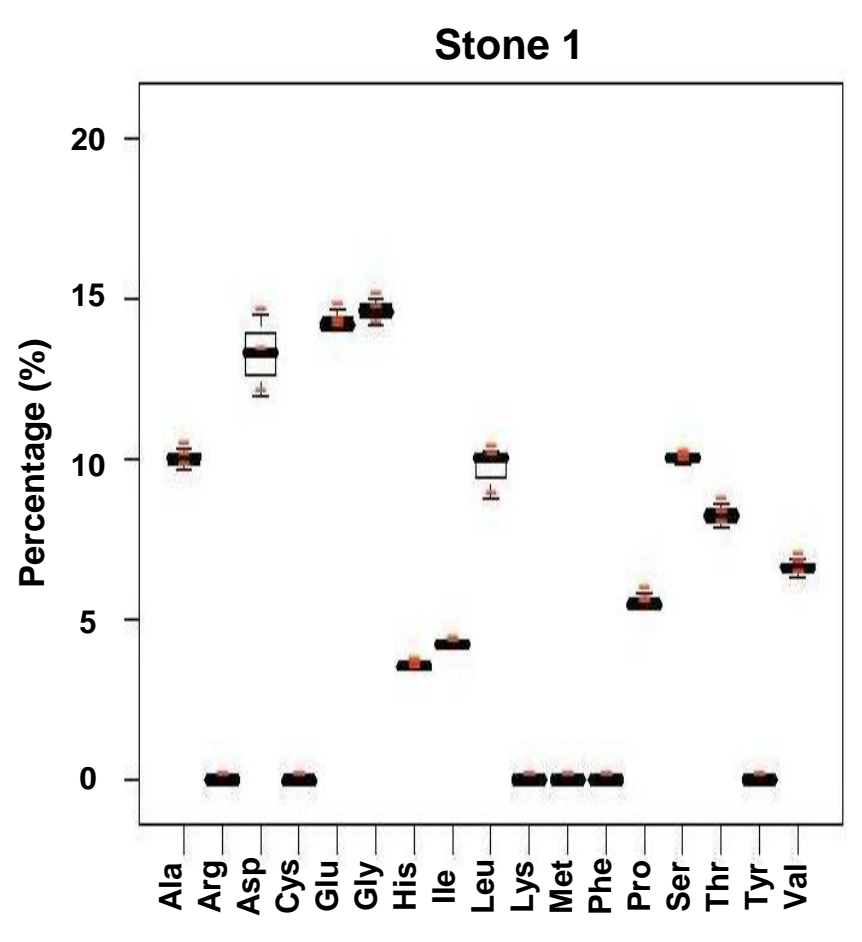

Amino acids

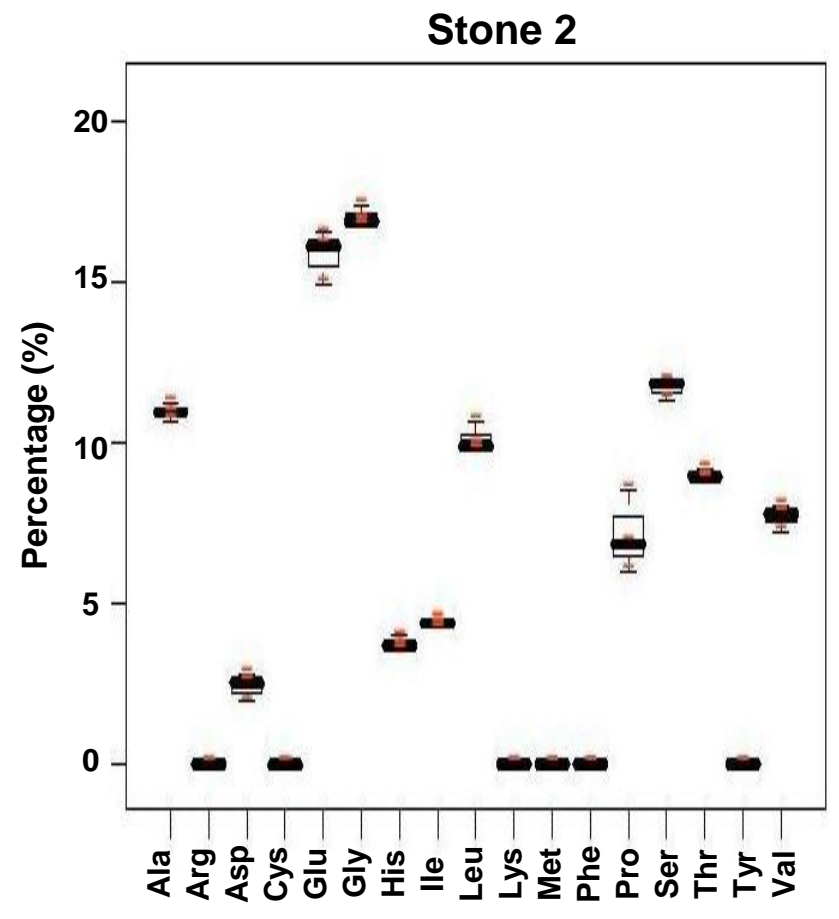

Amino acids

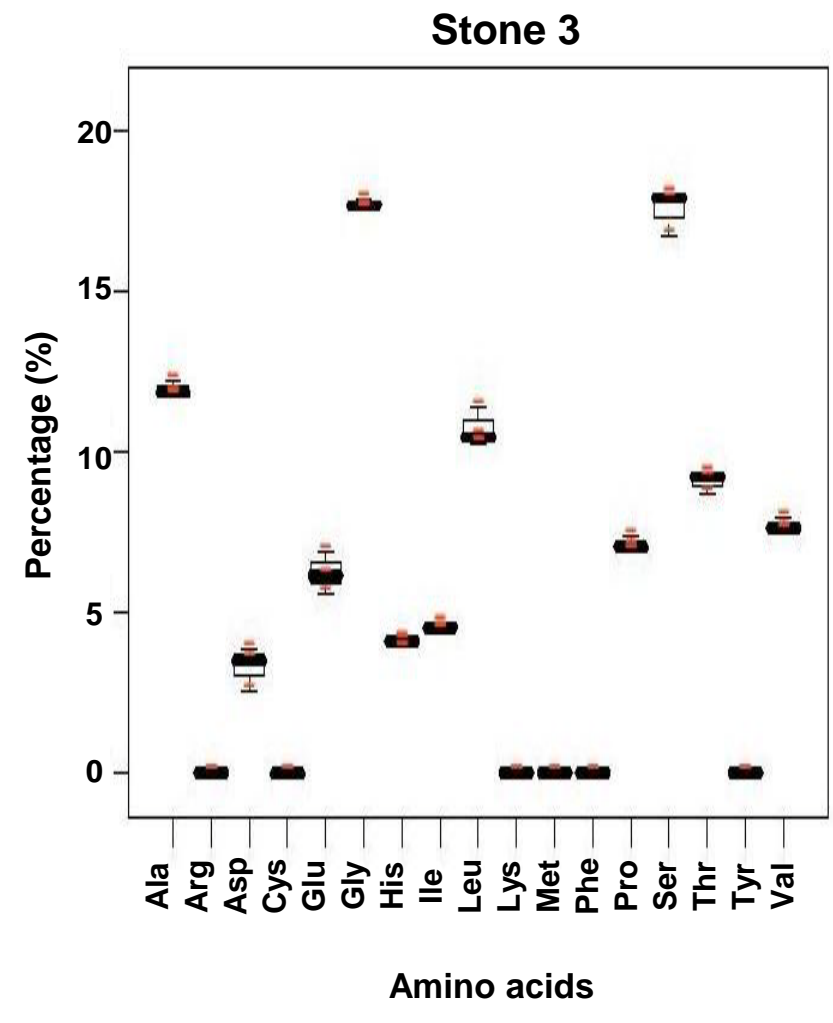

Figure 2 